\title{
MORPHOLOGICAL CHARACTERIZATION OF THE LARYNGEAL MOUND OF THE EGYPTIAN GEESE
}

\author{
SALMA A. MOHAMED; MOHAMMED ABDELSABOUR-KHALAF and \\ FATMA ABDELHAKEEM \\ Department of Anatomy and Embryology, Faculty of Veterinary Medicine, South Valley University, Qena, Egypt
}

Received: 15 November 2017; $\quad$ Accepted: 28 December 2017

\begin{abstract}
The current study was carried on thirteen adult healthy Egyptian geese (Alopochen aegyptiacus) of both sexes. The samples were processed for the morphological features of the laryngeal mound. The laryngeal mound was an oval elevation carried dorsally the glottis that continued caudally with short narrow laryngeal sulcus. The glottis measured $12.91 \pm 0.16 \mathrm{~mm}$ long and $2.88 \pm 0.22 \mathrm{~mm}$ wide, its rim was guarded by $8-9$ small caudally directed pointed papillae. The laryngeal mound was lined by respiratory epithelium; pseudostratified ciliated columnar type with goblet cells and intraepithelial glands. There were two types of intraepithelial glands; serous and mucous types. The mucous type lined by GAG producing cells, while the serous one lined by four different types of cells; GAG producing cells, secretory cells contained either large faintly stained granules or small dark blue stained granules and progenitor cells. Four groups of cricoarytenoid salivary glands could be identified within the submucosa on each side of laryngeal mound, in which two groups on each side of the laryngeal inlet and two groups in each side of the laryngeal sulcus.
\end{abstract}

Key words: Laryngeal mound, glottis, respiratory epithelium, intraepithelial glands.

\section{INTRODUCTION}

The Egyptian goose (Alopochen aegyptiacus), phylogenetically categorized to the order Anseriformes and the family Anatidae, is a mediumsized aquatic bird, mostly demonstrated in Africa, especially in the Nile Valley and south of the Sahara desert (Newman, 1983). The respiratory system in the birds is remarkably different from that of mammals morphologically and physiologically. The laryngeal mound does not have epiglottis and vocal cords, so cannot making voice (Pesek, 2000). The laryngeal mound was studied in some birds by several authors (McLelland, 1990; Bacha and Bacha, 2000; Kabak et al., 2007; Ibe et al., 2008; AL-Mussawy, 2011), while it is absent in ostrich and the larynx projects from the pharyngeal floor (Tadjalli et al., 2008). Because of the shortness of data concerning the morphological characters of the laryngeal mound of geese, this research aims to give a precise information on morphological features of the laryngeal mound of Egyptian geese.

Corresponding author: Dr. Mohammed Abdelsabour-Khalaf E-mail address: moh_abdelsabour@yahoo.com

Present address: Department of Anatomy and Embryology, Faculty of Veterinary Medicine, South Valley University, Qena, Egypt

\section{MATERIAL AND METHODS}

Thirteen healthy adult Egyptian geese aged three to four months were used in the present study. The heads were collected directly after slaughtering and submerged in $10 \%$ neutral buffered formalin for $48 \mathrm{~h}$, then washed in running tap water, and cut along one angle of the mouth to exhibit the laryngeal mound. The macroscopical characters of the laryngeal mound were described and photographed using Iphone $4 \mathrm{~S}$ camera. Then several dimensions were measured using Vernier Caliper (Table1). For light microscopical investigation, the samples were processed for paraffin embedding. Sections were cut at $3-5 \mu \mathrm{m}$ thickness and stained with several stains: Harris's Haematoxylin and Eosin (H\&E), Periodic Acid - Schiff's reagent (PAS) and Alcian blue. All stain techniques were adopted after (Bancroft and Gamble, 2002). For SEM, the specimens of the laryngeal mound were taken, fixed in a sodium cacodylate buffered solution of $2 \%$ glutaraldehyde and $2 \%$ paraformaldehyde for $24 \mathrm{~h}$. Pieces of the sample were washed in $0.1 \mathrm{M}$ phosphate buffer at $\mathrm{pH}$ $=7.4$, then dehydrated in ascending grades of ethanol followed by critical point-dried in liquid carbon dioxide followed by mounting onto stubs, and sputter coated with palladium and gold in a Bal-Tec sputter coater. Specimens were examined and photographed using JEOL scanning electron microscopy (JSM5400). For semithin sections, another samples were 
fixed also in 2 gluteraldehyde and $2 \%$ paraformaldehyde at $4{ }^{\circ} \mathrm{C}$, post fixed in $1 \%$ osmium tetraoxide, dehydrated in ascending grade of acetone then embedded in spur's resin. Semithin sections $(0$.
$5 \mu \mathrm{m})$ were cut by ultramicrotome and stained with toluidine blue. The nomenclature used in this work is that adapted by Nomina Anatomica Avium (Baumel, 1993).

Table 1: Dimensions (mm) of the laryngeal mound.

\begin{tabular}{lc}
\hline Measurements & Mean \\
\hline Length of: & $32.01 \pm 0.81$ \\
-pharyngeal floor. & $22.34 \pm 0.27$ \\
-laryngeal mound. & $69.91 \%$ \\
\hline Ratio (\%) of length of: & \\
-laryngeal mound to pharyngeal floor. & $12.91 \pm 0.16$ \\
\hline Laryngeal inlet: & $2.88 \pm 0.22$ \\
-length. & $8-9$ \\
-width at the middle. & \\
-number of papillae on its rim. & $6.76 \pm 0.51$ \\
\hline Longitudinal row of papillae. & $4-5$ \\
\hline -length. & $8.81 \pm 0.28$ \\
-number of papillae. & \\
\hline Length of laryngeal sulcus & \\
\hline
\end{tabular}

\section{RESULTS}

The laryngeal mound (Mons laryngealis) was a raised oval structure projected dorsally from the caudal part of the pharyngeal floor. It characterized by two longitudinal rows of caudally and slightly laterally directed pharyngeal papillae one on each side of its rostral third. Each row measured $6.76 \pm 0.51 \mathrm{~mm}$ long and consisted of 4-5 papillae (Table1 \&Fig.1). The rostral half of the laryngeal mound contained laryngeal inlet (glottis) which lied directly opposite to the wide caudal part of choanal slit. It had rostral and caudal commissures in which the rostral one was

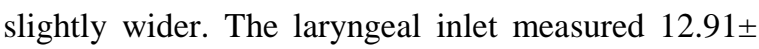
$0.16 \mathrm{~mm}$ long and it was wider at its middle $(2.88 \pm 0.22 \mathrm{~mm})$ than at its both commissures. The caudal commissure continued caudally with a short narrow laryngeal sulcus, which measured 8.81 \pm 0.28 mm long (Table1 \& Fig.1). Each rim of the laryngeal inlet was guarded by a sagittal row of 8-9 small caudally directed pointed papillae which decreased in size caudal wards. By SEM, These papillae showed exfoliated cells, which were concentrated around their roots (Fig.2). Behind to the laryngeal inlet, the dorsal aspect of the laryngeal mound was characterized by numerous closely packed caudally directed and different sized pharyngeal papillae (Papillae pharyngeals) (Fig.1). These papillae were irregularly distributed, except the most rostral ones which were arranged in a transverse row extending caudolaterally from the caudal commissure. Moreover, the laryngeal sulcus was guarded by a sagittal row of caudally directed conical papillae which decreased in size caudal wards (Fig.1). By SEM, the pharyngeal papillae appeared elongated conical in shape with pointed apices, some of them had broad roots. It was noticed that some of these papillae were bi- or trifurcated. The laryngeal sulcus showed nearly longitudinal folds, some desquamated cells were observed over these folds (Fig.2).

The laryngeal mound was covered by stratified squamous epithelium, which represented the continuation of that of the surrounding pharyngeal floor. Epithelial parakeratinization was apparent only on pharyngeal papillae. The laryngeal inlet was lined by stratified squamous epithelium which gradually transformed into stratified squamous epithelium with intraepithelial mucous glands then into respiratory epithelium (Fig. 3A, B, C). The respiratory epithelium which lined the whole laryngeal mound, appeared as pseudostratified ciliated columnar type with goblet cells and intraepithelial glands (Fig 3D). Moreover, solitary Herbst corpuscles were located near the laryngeal inlet below its covering epithelium (Figs. 3E). The respiratory epithelium was formed of different types of cells. The principle cells were long ciliated columnar, which were differentiated by toluidine blue into two types of cells; light and dark. The basal cells were small, short and did not reach the epithelial surface. Some epithelial cells stained positive for Alcian blue and others positive for PAS stain (Fig.3D). Goblet cells represented unicellular glands interspersed among the other cells. They appeared cylindrical in shape with expanded apical part filled with mucigenic granules and the basal part contained an oval nucleus (Fig. 3C). Multicellular intraepithelial glands were slightly invaginated from the respiratory epithelial surface. These were either simple or compound type. Glandular cells arranged in a radial manner around a small central lumen. The intraepithelial glands were exocrine glands connected to short ducts which opened into the laryngeal cavity. The ductal epithelium was pseudostratified ciliated columnar epithelium. Two types of intraepithelial glands could be observed within the respiratory 
mucosa; mucous and serous types. By toluidine blue, the mucous glands were lined by glucoseaminoglycan (GAG) secreting cells, which were columnar in shape with oval basally located nuclei and the cytoplasm was rich in metachromatic granules. While the serous type contained many types of cells; GAG producing cells, secretory cells contained either large, faintly stained granules or small darkly blue stained granules and progenitor (basal) cells (Figs.4F-I).

The submucosa of the cranial part of the laryngeal mound contained two groups of salivary glands; rostromedial and rostrolateral cricoarytenoid glands, which were located on both sides of the rostral part of laryngeal inlet ((Figs.4A-D). Another two groups of salivary glands were demonstrated within the submucosa on both sides of the laryngeal sulcus; caudomedial and caudolateral cricoarytenoid glands (Figs.5A-E). These glands were tubuloalveolar mucous glands, lined by high columnar cells with flat basally located nuclei and foamy highly vacuolated cytoplasm. Semithin sections showed rostrolateral cricoarytenoid glands dominated by GAG producing cells with abundant metachromatic granules, secretory cells contained large, faintly stained granules and secretory cells large vacuoles (Figs.4AE). The pharyngeal surface had small conical parakeratinized pharyngeal papillae at the laryngeal inlet while at the caudal part of the laryngeal mound many different sized highly parakeratinized papillae were observed. These papillae were formed of connective tissue core covered by parakeratinized (nucleated keratinized) stratified squamous epithelium (Figs.3A, 4A, 5A, B). Bundles of skeletal muscles connecting laryngeal cartilages represented the intrinsic laryngeal muscles and the other bundles surrounding the laryngeal cartilages represented the extrinsic laryngeal muscles were demonstrated (Figs $5 \mathrm{~A})$.

\section{LEGENDS OF FIGURES:}

Figure 1A-B: Photographs of the dorsal aspect of the laryngeal mound showing: lingual root (r), laryngeal mound (lm), glottis (g), caudal pharyngeal papillae (pp), esophagus (o), laryngeal sulcus (red arrow), pharyngeal floor (green line), rostral longitudinal rows of pharyngeal papillae (red arrowheads), papillae at rim of glottis (black arrow).

Figure 2A-D: Scanning electron micrographs of the caudal pharyngeal papillae showing: conical pharyngeal papillae (spiral arrow), broad root pharyngeal papillae (barbed arrow), bi- or tri-furcated pharyngeal papillae (white arrows), laryngeal sulcus (white asterisk), longitudinal folds with desquamated cells in laryngeal sulcus (white arrowhead).
Figure 3A-E: photomicrographs showing changes in the lamina epithialis of the laryngeal mound: $A$ : epithelial transition from stratified squamous epithelium (STEp) to Respiratory epithelium (Rep) with intraepithelial glands (blue arrow), arytenoid cart. (A), rostromedial cricoarytenoid (RMcr). B: stratified squamous epithelium (STEp) with intraepithelial glands (g). C, D: Respiratory epithelium appeared pseudo-stratified ciliated (C) with goblet cells (blue asterisk), two types of ciliated principle cells; dark cell (red arrowhead) and light cell (green arrowhead). E: Herbset corpuscle (H), the covering stratified squamous epithelium (STEp) with intraepithelial glands (g). Paraffin sections stained by $\mathrm{H} \& \mathrm{E}(\mathrm{A}, \mathrm{B}, \mathrm{C}, \mathrm{E})$ and semithin sections stained by toluidine blue (D).

Figure 4A-I: photomicrographs of the Laryngeal mound showing: rostromedial cricoarytenoid gland (RMcr), rostrolateral cricoarytenoid gland (RLcr), laryngeal inlet (LI), muscle (M), stratified squamous epithelium (STEp), Respiratory epithelium (Rep), arytenoid cartilage (A), Tracheal cartilage (TC). C, E: GAG producing cells with metachromatic granules (blue arrowheads), secretory cells contained faintly stained granules (black arrowheads), secretory cells with large vacuoles (green arrow). F: the mucous intraepithelial gland (red arrowhead). G: the serous intraepithelial gland (blue arrowhead). $\mathrm{H}$ : the mucous glands lined by glucoseaminoglycan (GAG) secreting cells, faintly stained metachromatic granules (yellow arrowhead), deeply stained metachromatic granules (green arrow head). I: the serous gland contained many types of cells; GAG producing cells (Yellow asterisk), secretory cells contained large, faintly stained granules (red asterisk), secretory cells contained small darkly blue stained granules (white asterisk) and the progenitor (basal) cells (green asterisk). Paraffin sections stained by $H \& E$ (A, B, D, F, G) and semithin sections stained by toluidine blue (C, E, H, I).

Figure 5A-F: photomicrographs of the pharyngeal floor: A: cross section in the pharynx showing: pharyngeal s.g. (Psg), pharyngeal muscles (PM), laryngeal cavity (LC), Internist Muscle (IM), Extrinsic Muscle (EM), the pharyngeal floor (squared area). B: small conical parakeratinized pharyngeal papillae (PP) covered by parakeratinized epithelium, laryngeal sulcus (LS). C, D: caudolateral cricoarytenoid glands (CLcr) were lined by mucous secreting cells (black arrowheads). E, F: caudomedial cricoarytenoid glands (CMcr) were lined by mucous secreting cells (black arrowheads). Paraffin sections stained by H\&E. 
Fig. 1
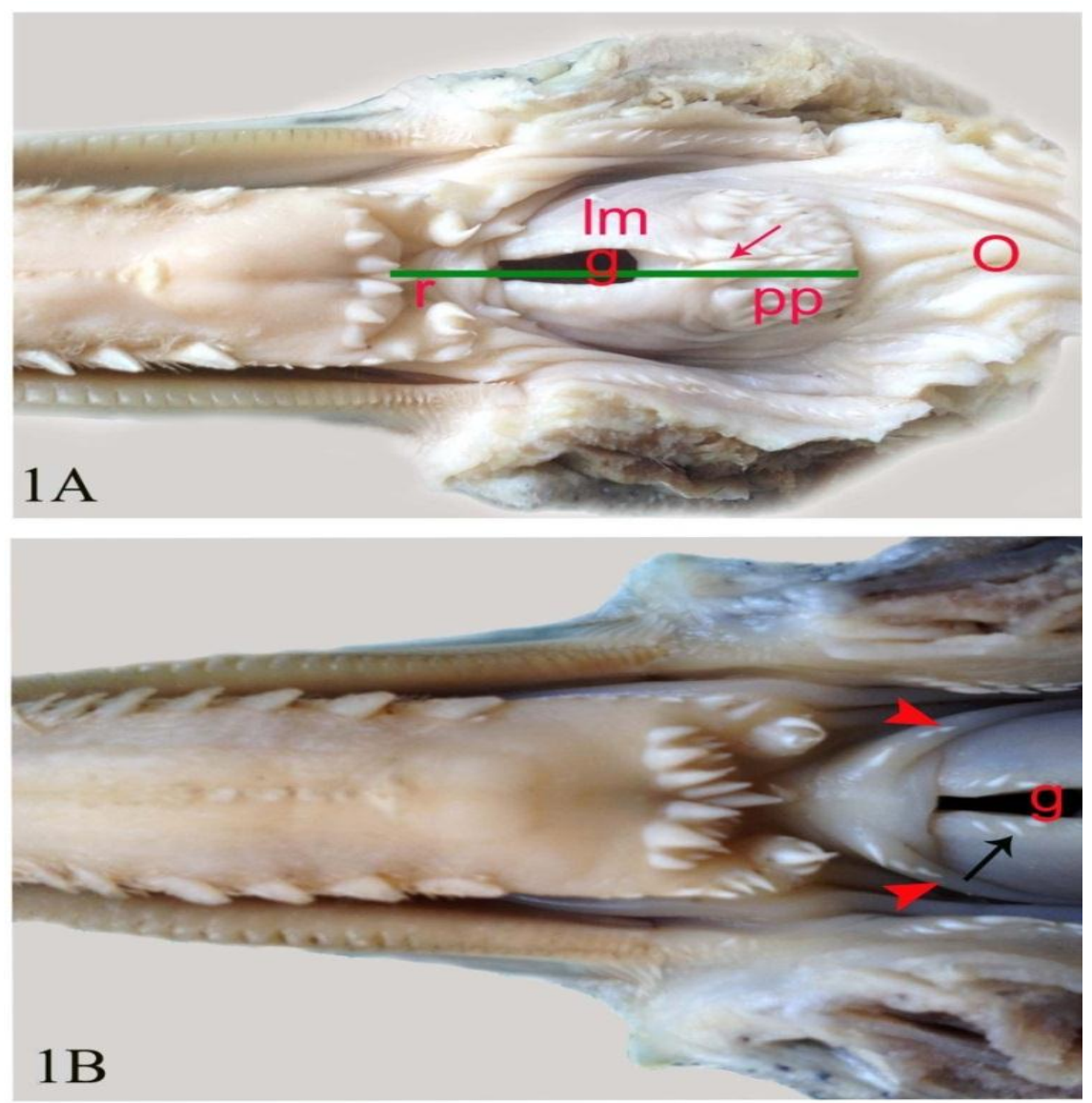

Fig. 2
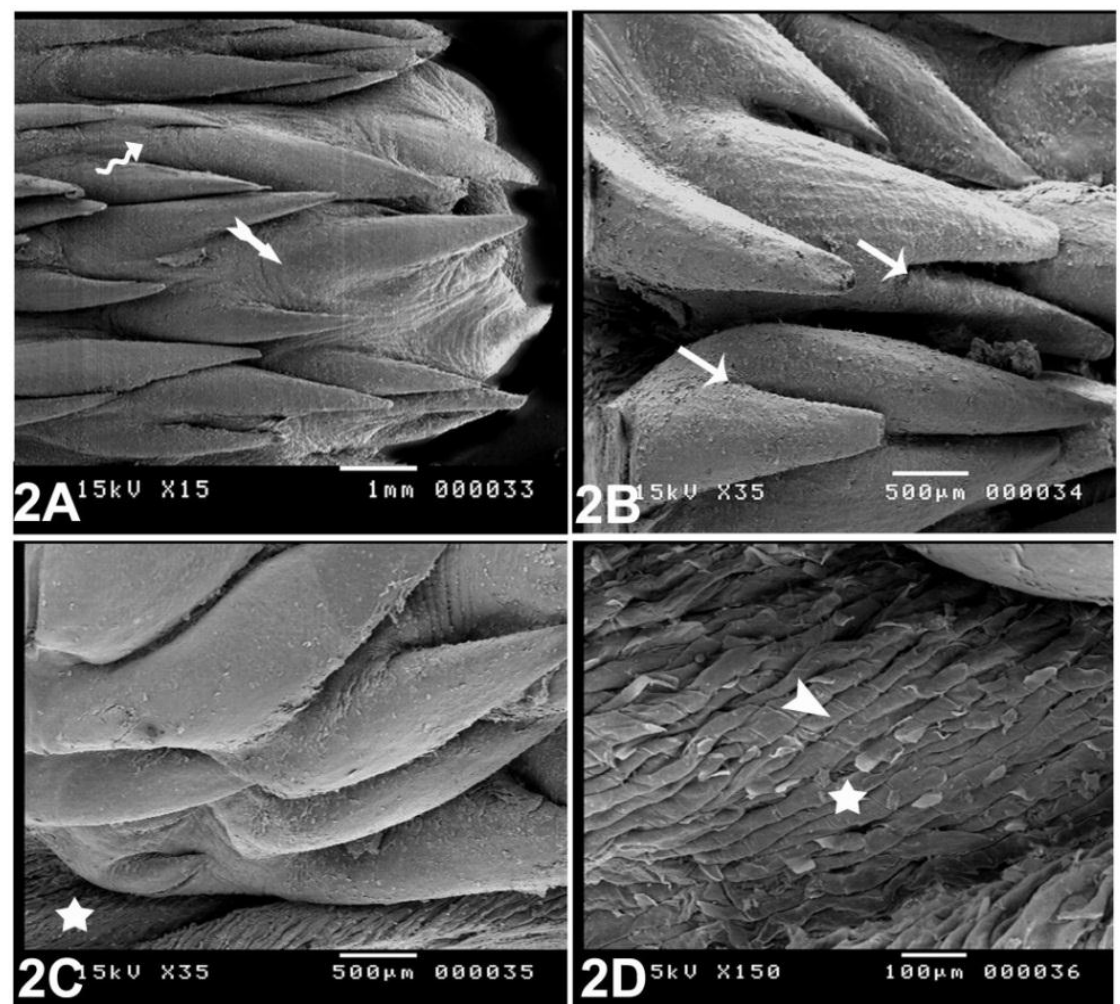

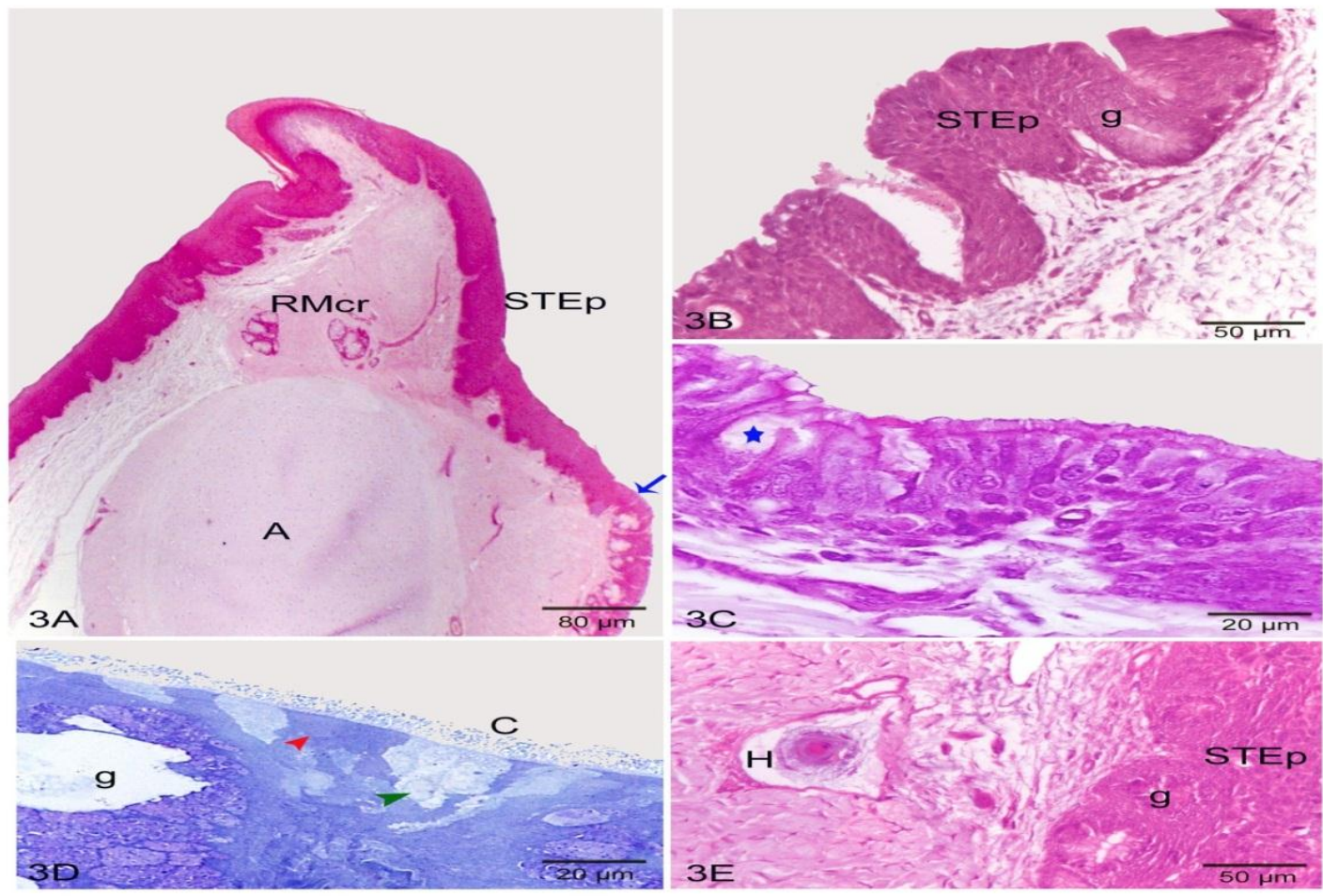

Fig. 3

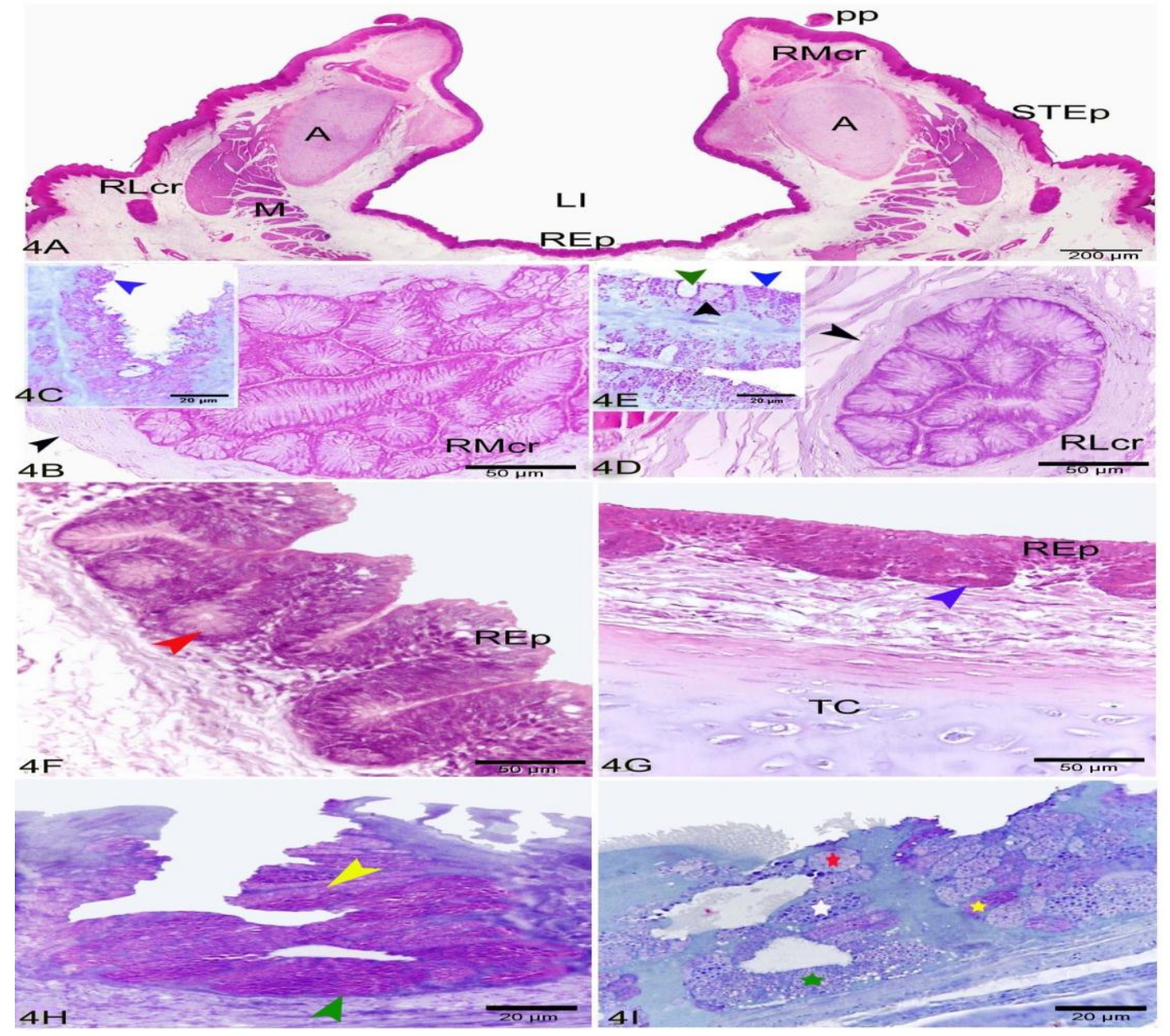

Fig. 4 


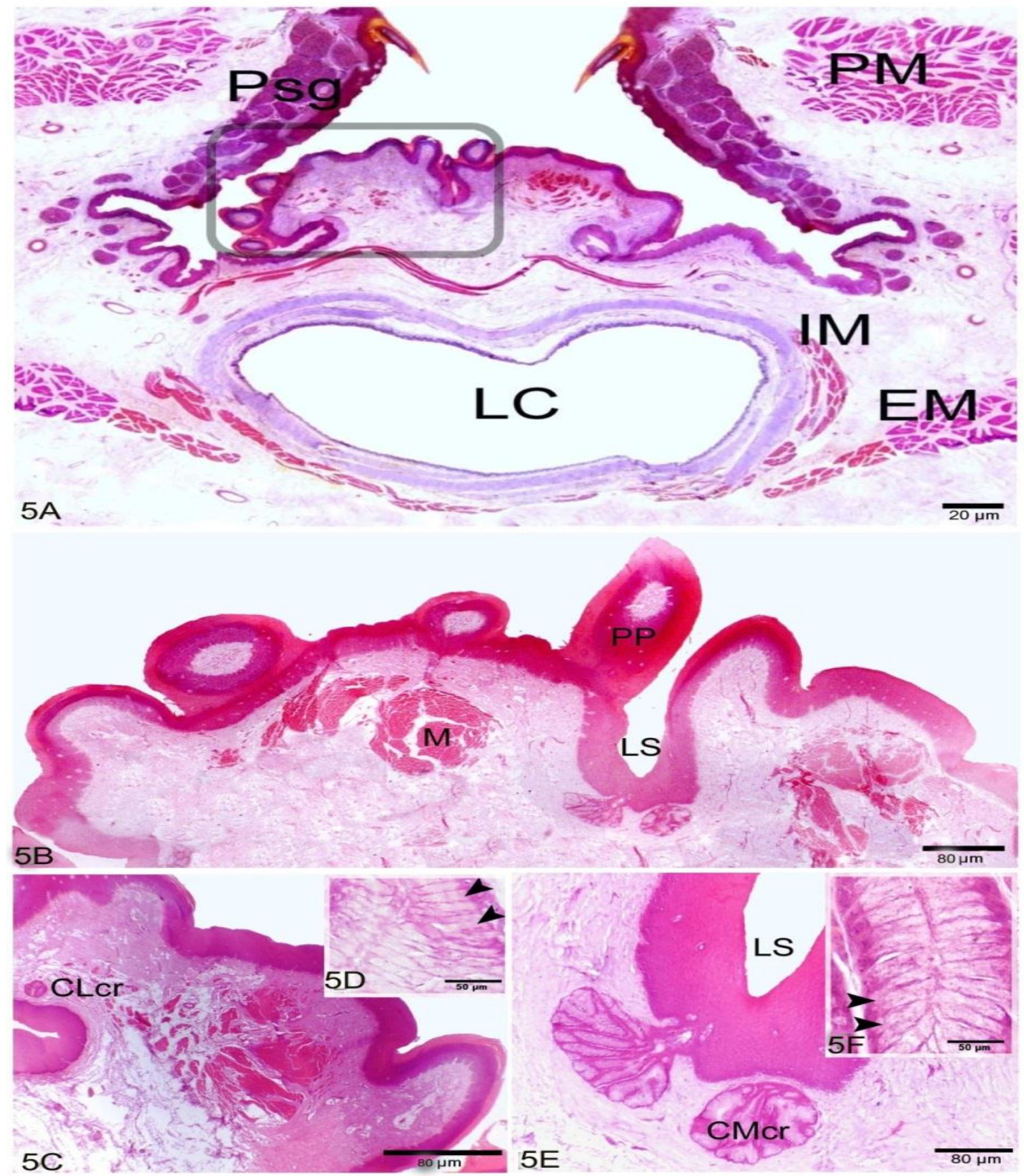

Fig. 5

\section{DISCUSSION}

The present findings showed that the laryngeal inlet (glottis) located in the rostral half of the laryngeal mound, it was situated opposite to the wide caudal part of choanal slit. Similar results were recorded in house sparrow and columba, but it was situated somewhat caudal to the choana as in the common kestrel (King and McLelland, 1979). When the beak was closed the glottis was perfectly aligned with the common openings of the choana in the caudal region of the roof of the oropharynx (Rodrigues et al., 2012). Concerning to the length of the glottis variations were recorded in the obtained literature, it was $11 \mathrm{~mm}$ in chicken, $15 \mathrm{~mm}$ in turkey and $13 \mathrm{~mm}$ in duck and goose (White, 1975). In turkey was $13.6 \mathrm{~mm}$ long (Saleh, 2013). In the examined geese, the glottis measured $12.91 \pm 0.16 \mathrm{~mm}$ long. However very long glottis was found in ostrich measuring $33.3 \mathrm{~mm}$ (Tadjalli et al., 2008). With regards to the width of the glottis, it was $2.88 \pm 0.22 \mathrm{~mm}$ in the examined geese. It is clarified that the glottis of the geese is narrower than the other birds which their width measured $3.2 \mathrm{~mm}$ in turkey (Saleh, 2013), $5.0 \mathrm{~mm}$, $3.0 \mathrm{~mm}$ and $4 \mathrm{~mm}$ in turkey, duck and goose respectively (White, 1975). The width of the laryngeal inlet varies functionally reaching a maximum during gasping (White, 1969). Functionally, in birds the glottis is unlike that of the mammals, it is not covered by an epiglottis. There is 
no soft palate, but the Rima glottis regulates the passage of air by a dilator and constrictor muscle that prevents aspiration of food material. The larynx plays no role in sound production (King and McLelland, 1984).

Over the laryngeal mound of the examined geese, numerous closely packed caudally directed and different sized pharyngeal papillae occupied the area behind to the laryngeal inlet. While in all studied ages of post hatching muscovy ducks, groups of pharyngeal papillae were demonstrated on both sides of the laryngeal sulcus (Mohamed, 2010). In chicken, each side of the laryngeal mound bears four rows of caudally pointing papillae(White, 1969). In turkey, the laryngeal mound was marked caudally by two transverse rows of conical caudally directed papillae (Saleh, 2013). In red jungle fowl, a single row of pharyngeal papillae was observed behind the laryngeal cleft (Kadhim et al., 2013). While in ostrich the papillae were not visualized on the larynx (Tadjalli et al., 2008). The backwards pointing cornified papillae of the mound assisted in the ingestion of the solid particles and helped in the raking movement of the larynx during swallowing (White, 1975; King and McLelland, 1984; Fitch, 1994). Corresponding to the present study, the rostral commissure of the laryngeal inlet was slightly wider than the caudal commissure. The rim of the inlet was guarded by a sagittal row of 8-9 small papillae. In this situation, the inlet of the turkey had rostral wide and caudal narrow commissures (Saleh, 2013). He added that the rim of the laryngeal inlet appeared smooth. Crole and Soley, (2010) confirmed these findings that the glottis was wide rostrally and narrow caudally. This is attributable to the lateral divergence of the arytenoid cartilages as they were proceeded rostrally. The glottis in ostrich was wide therefore the general appearance of the larynx in ostrich was different from other domestic birds (Tadjalli et al., 2008).

The current study revealed that, the stratified squamous epithelium of the pharynx lined the dorsal surface of the laryngeal mound till the inlet where it transformed into respiratory epithelium. Similar observations were documented in different species as muscovy duck, chicken and turkey (Mclelland, 1975; Mohamed, 2010; Saleh, 2013). The last author added that the stratified squamous epithelium was keratinized. The present findings revealed that the laryngeal mound was lined by pseudo stratified ciliated columnar epithelium with unicellular goblet cells and many intraepithelial glands. A similar observation was described in birds (Banks, 1993; Fath El-Bab, 2004). The present findings described multicellular intraepithelial glands within the respiratory mucosa which either simple or compound mucous and serous types. The mucous glands were lined by GAG secreting cells and the serous glands contained many types of cells; GAG producing cells, secretory cells contained large faintly stained granules, secretory cells contained small darkly stained granules and the progenitor cells. However, Samuelson (2007) in birdsand Saleh (2013) in turkeydescribed only simple tubular mucous glands in the pseudo-stratified ciliated columnar epithelium. The later author added that the mucous glands were lined by columnar mucous secreting cells with flat basally located nuclei.

The dorsal surface of the laryngeal mound of the examined geese was interrupted by the openings of cricoarytenoid salivary glands which were four groups of mucous alveolar salivary glands. These findings were in agreement with that mentioned by Mohamed (2010) in muscovy ducks. In the examined geese the secretory units of the cricoarytenoid salivary glands were lined by mucous secreting cells showing strongly positive PAS/Alcian blue reaction. These results indicated that the mucous secreting cells secrete both acidic and neutral mucopolysaccharides. However, in turkey Saleh (2013) stated that the glandular tubules of the cricoarytenoid salivary glands were lined by mucous secreting cells showing strongly positive PAS reaction which indicating the presence of neutral mucopolysaccharides.

\section{ACKNOWLEDGEMENT}

The authors would like to thank South Valley University for financially supporting this study.

\section{REFERENCES}

AL-Mussawy, A. (2011): Anatomical and Histological Study of Major Respiratory Organs (Larynx, Trachea, Syrinx, Bronchi and Lungs) In Indigenous Male Turkey (Meleagris gallopava). MS Thesis. AL-Qadisiya Uni. Vet. Med. College.

Bacha, W.J. and Bacha, L.M. (2000): Color Atlas of Veterinary Histology 2nd (ed.). Lippincott Williams \& Wilkins., PP: 175-190.

Bancroft, J. and Gamble, M. (2002): Theory and practice of histological techniques. $5^{\text {th }}$ London Edinburgh New York Philadelphia St. Louis Sydney Toronto.

Banks, W.J. (1993): Applied Veterinary Histology. $3^{\text {rd }}$ Ed., Mosby-Year Book, Inc., London and Philadelphia.

Baumel, J.J. (1993): Handbook of avian anatomy: nomina anatomica avium. Publications of the Nuttall Ornithological Club (USA). no. 23.

Crole, M. and Soley, J. (2010): Gross Morphology of the Intra-Oral rhamphotheca, Oropharynx and Proximal Oesophagus of the Emu (Dromaius novaehollandiae). Anatomia, histologia, embryologia 39, 207-218.

Fath El-Bab, M.R. (2004): Fundamentals of the Histology of Birds,. $1^{\text {st }}$ Ed. An Introductory Text for Veterinary Students. . 
Fitch, W.T.S. (1994): Vocal tract length perception and the evolution of language. $\mathrm{PhD}$ thesis. Brown University B. A. Biol. Pp. 1-95.

Ibe, C.S.; Onyeanusi, B.; Salami, S.; Umosen, A. and Maidawa, S. (2008): Studies of the major respiratory pathways of the West african guinea fowl (Numida meleagris galeata): The Morphometric and Macroscopic Aspects. Inter. J. of Poul. Sci 7, 997-1000.

Kabak, M.; Orhan, I. and Haziroglu, R. (2007): The Gross Anatomy of Larynx, Trachae and Syrinx in the Long-Legged Buzzard (Buteo rufinus). Anatomia, histologia, embryologia 36, 27-32.

Kadhim, K.K.; Zuki, A.; Babjee, S.; Noordin, M. and Zamri-Saad, M. (2013): Morphological and histochemical observations of the red jungle fowl tongue Gallus gallus. African Journal of Biotechnology 10, 9969-9977.

King, A.S. and McLelland, J. (1979): Form and Function in Birds. Academic press Inc. (London) Ltd. London, New York, Toronto, Sydney, San Francisc.

King, A.S. and McLelland, J. (1984): Birds their Structure and Function. $2^{\text {nd }}$ Ed. Bailliere Tindall, London.

Mclelland, J.(1975): Aves Digestive System: In Sission and Grossman's, The Anatomy of the Domestic Animals, Rev. R. Getty. W. B. Saunders Company, Philadelphia, London, Toronto, Sydney and Tokyo. Vol. 2, 2, $5^{\text {th }}$ Ed.

McLelland, J. (1990): A colour atlas of avian anatomy. Wolfe Medical Publications Ltd.

Mohamed, A.A. (2010): Some developmental studies on the floor of the oropharynx of the duck.
Master Thesis. Faculty of Vet. Med. South Valley University.

Newman, K. (1983): Newman's birds of southern Africa. MacMillan, Johannesburg.

Pesek, L. (2000): The avian respiratory system. Winged Wisdom Pet Bird Magazine 1: 1-3.

Rodrigues, M.N.; Tivane, C.N.; Carvalho, R.C.; Oliveira, G.B.; Silva, R.S.; Ambrosio, C.E.; Oliveira, M.F. and Miglino, M.A. (2012): Gross morphology of rhea oropharyngeal cavity. Pesquisa Veterinária Brasileira 32, 5359.

Saleh, A.M. (2013): Macro- and Micromorphological studies on the laryngeal mound of Turkey. Assiut Vet. Med. J. 59, 88-94.

Samuelson, D.A. (2007): Textbook of veterinary histology. Saunders-Elsevier.

Tadjalli, M.; Mansouri, S.H. and Poostpasand, A. (2008): Gross anatomy of the oropharyngeal cavity in the ostrich (Struthio camelus). Iranian Journal of Veterinary Research 9, 316323.

White, S.S. (1969): Larynx In: Sission and Grossman's, The Anatomy of the Domestic Animals. Rev. R. Getty. W.B. Saunders Company, Philadelphia, London, Toronto, Sydney and Tokyo. Vol. 2, 5th Ed.,.

White, S.S. (1975): Larynx In: Getty R, Rosenbaum CE, Ghoshal NG, Hillmann D (eds) Sission and Grossman's The Anatomy of the Domestic Animals. Saunders Company, Philadelphia, vol 2. , pp: 1891-1897.

\section{التوصيف الظاهري للتلة الحنجرية في الاوز المصري \\ سلكي /حد محمد ، محمد عبل الصبور /حد خلف ، فاطمة عبد الحكيم

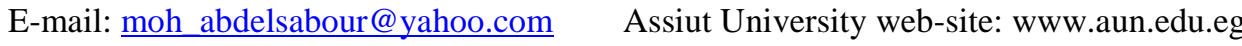

\footnotetext{
أجريت الدراسة الحالية على ثلاثة عشر من الأوز البالغ المصرى (ألوبوشن إجيبتياكوس) من كلا الجنسين. تمت معالجة العينات

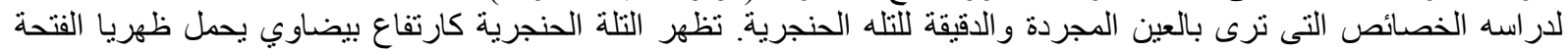

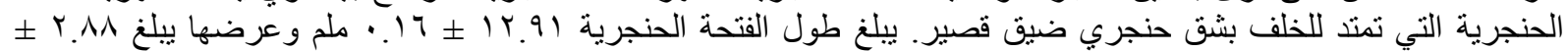

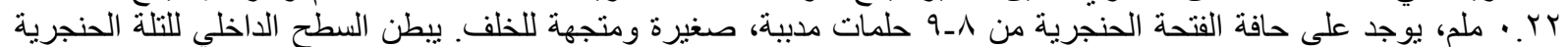

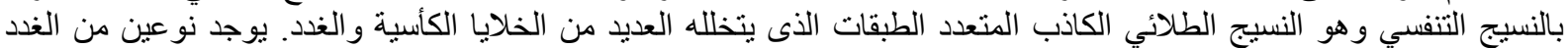

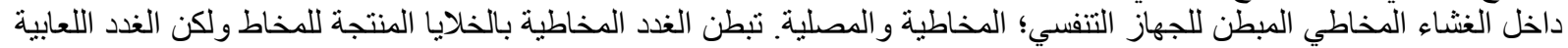

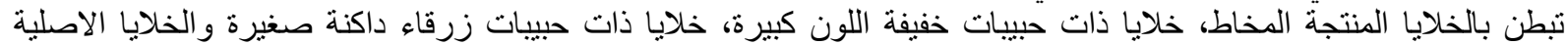
(البدائية). يمكن تمييز على أربع مجمو عات من الغدد اللعابية الحلقية على كل جانب للتلة الحنجرية في الطبقة تحت البطانة المخاطية.
} 